\title{
Os viajantes naturalistas do século XIX e suas contribuições para o conhecimento científico das línguas e culturas dos povos nativos das Américas
}

Os viajantes naturalistas do século XIX foram grandes colecionadores. Ao revisarmos os inventários dos volumosos envios que estes expedicionários regularmente realizaram, ainda durante o percurso dos seus périplos, constatamos que o leque dos seus interesses era muito abrangente. A depender das instruções que dirigiam suas tarefas, colecionavam plantas, animais, amostras de minerais, vistas das paisagens, objetos da cultura material dos povos e, também, palavras de línguas cujo significado com frequência apenas conseguiam adivinhar. No olhar retrospectivo, o afã compilador se apresenta como o empenho destes personagens, e dos seus comitentes, por construir representações amplas do mundo que haviam visitado. Mais do que meros gabinetes de curiosidades reunidos um pouco ao acaso, as coletas dos viajantes naturalistas aspiravam a constituir-se em sínteses, com uma pretensão de sistematicidade científica, sobre os territórios percorridos.

Neste contexto, as amostras de vocábulos ocupam um lugar singular na aproximação ao conhecimento do homem. As palavras compiladas são conjuntos de objetos imateriais transformados em peças colecionáveis através dos registros em papel, cobiçados pelos eruditos europeus; tratam-se de corpos documentais que circularam amplamente e foram objeto das mais diversas tentativas de sistematização. Sabemos, por exemplo, que as listas de palavras reunidas pelo zoólogo austríaco Johann Natterer ao longo de quase duas décadas no interior da América do Sul foram entesouradas pelo renomado americanista e estudioso das culturas e línguas do planalto andino do Peru e Bolívia, Johann Jacob von Tschudi, que administrou cautelosamente esses bens, dando-os a conhecer em pequenas doses entre os seus contemporâneos. Wilhelm von Humboldt, por sua vez, estabeleceu uma complexa rede de contatos com o objetivo de ter acesso às mais diversas compilações e registros das línguas americanas, no intuito de compor uma abrangente série de estudos gramaticais executados em seu gabinete berlinense. E o naturalista C.F.Ph. von Martius passou quase meio século empenhado em enriquecer as suas próprias coletas de amostras linguísticas - reunidas durante a sua viagem pelo Brasil -, com as 
compilações de viajantes de toda a Europa que, como ele, também visitaram as terras americanas.

Ao apresentarmos aqui uma série de investigações monográficas sobre essas coleções e os estudos a que foram submetidas, temos pretendido oferecer um panorama amplo das modalidades de trabalho que foram aplicadas na execução das pesquisas linguísticas, e dos objetivos que impulsionaram a execução dessa intrincada tarefa.

Nosso ponto de partida são os viajantes naturalistas do século XIX, alguns que foram verdadeiros expedicionários e se aventuraram a explorar as diversas paisagens culturais americanas, outros que viajaram de forma vicária, transpondo-se por via do intelecto e utilizando as fontes que lhes foram fornecidas por terceiros.

Personalidades emblemáticas que pertencem à categoria dos expedicionários são o zoólogo Natterer e o botânico Martius, os quais, na primeira metade do século XIX, ousaram incursionar para além dos territórios temáticos das suas disciplinas, adentrando no conhecimento das línguas indígenas da América do Sul. A uma geração posterior, mas com a mesma vocação intelectual, herdeira do Século das Luzes, pertence o arqueólogo, etnólogo e linguista alemão Max Uhle, que na virada do século XIX para o XX percorreu e pesquisou sobre a história dos povos americanos no território andino. O espaço das sociedades Maya reúne, por sua vez, num período de pouco mais de meio século, uma diversidade de investigadores que incluem desde o fazendeiro Erwin Dieseldorff, um amador das pesquisas históricas e antropológicas, com particular atenção às línguas, até o cientista Karl Sapper.

Numa perspectiva da História das Ciências, essas figuras têm se tornado imprescindíveis no panorama do saber sobre o homem americano. É a esses personagens que se dedicam os primeiros estudos que compõem o presente dossiê temático.

Porém, cientes de que as pesquisas linguísticas têm uma longa tradição no nosso continente, incluímos dois destacados exemplos do período colonial nas personalidades de dois sacerdotes jesuítas: Antonio Ruiz de Montoya e seus estudos do Guaraní, de inícios do século XVII, e Filippo Salvatore Gilij, do XVIII, com seus trabalhos abrangentes sobre os povos e suas manifestações culturais, especialmente no âmbito da língua, na bacia do Orenoco.

E como um contraponto ao espírito evangelizador e colonizador de Montoya e Gilij, e ao impulso ilustrado de Martius, Natterer, Uhle e, sobretudo, de Wilhelm von Humboldt, incluímos também artigos monográficos com aproximações sobre a vida e o trabalho de três estudiosos das línguas americanas no século XX: Rodolfo Lenz e o Mapudungun, Franz Caspar e o Tuparí e James Barker e 
o Yanomami. Esses autores trazem versões modernas de um afazer secular. Os dois primeiros, Lenz e Caspar, têm uma atitude que poderíamos qualificar de sacerdócio do saber. O terceiro, Barker, se nos apresenta dando continuidade a um tipo de estudo instrumental da língua: o uso da palavra numa língua indígena como forma de contribuir à propagação da Palavra dos evangelhos cristãos.

Todos esses personagens percorreram o território americano e procuraram desvendar os segredos das línguas de povos com os quais estabeleceram contato. Todos eles tiveram consciência da importância de que, para uma aproximação com os americanos, seja qual for o propósito que os movesse, o conhecimento da língua era um requisito iniludível. Com o correr do tempo, essa necessidade do saber tem adquirido um caráter premente, mas com uma conotação bem diferente, diante da voragem homogeneizadora da nossa modernidade. Se, como dizia Leibniz, "a língua é o espelho da alma", os estudos daqueles pesquisadores das línguas nos fornecem valiosas peças para conhecer a diversidade do pensamento e do espírito humano.

Pablo Diener

Organizador desta edição 